\title{
The Characteristics of the Outpatient Utilisation of Medicines in the Republic of Srpska in the period 2009-2017
}

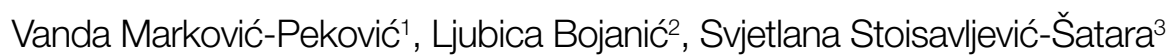

\section{ABSTRACT}

Background: Monitoring and measuring of the medicine utilisation enables to assess the quality of use of medicines, providing the evidence-based data for the improvement of the prescribing practice and a more rational use of medicines. The aim of this study was to analyse utilisation patterns of medicines and to compare the results with other countries.

Methods: A retrospective, observational study to analyse outpatient medicines utilisation in the Republic of Srpska between 2009 and 2017. Data of medicines utilisation were retrieved from the national database in the Public Health Institute of the Republic of Srpska and calculated and analysed by using the Anatomical Therapeutic Chemical/Defined Daily Dose (ATC/DDD) methodology. The results were expressed as Defined Daily Doses (DDDs) per 1,00o inhabitants per day.

Results: Total medicines utilisation increased, from 448 DDDs in 2009 to 1,036 DDDs in 2017. Cardiovascular medicines (group C) were the most used medicines, and their share in the total utilisation increased from $36.6 \%$ in 2009 to $44.4 \%$ in 2017. Among them, the most frequently used were angiotensin-converting enzyme inhibitors, plain and in combinations with diuretics, namely enalapril. The share of medicines used in diabetes in the total utilisation increased from 3.9\% in 2009 to $5.1 \%$ in 2017. Metformin and glimepiride accounted for about $83 \%$ of the blood glucose lowering medicines group (A10B). Among the antithrombotic medicines, the most frequently used were platelet aggregation inhibitors (Bo1AC), mainly acetylsalicylic acid whose use tripled since 2009. Diclofenac was the most frequently used non-steroidal anti-inflammatory and antirheumatic drug (Mo1).

Conclusion: The trend of increased medicines utilisation was observed in this study. This finding is comparable with other countries. Variations between countries in the preferred medicines within a class as well as the extent of medicines use were observed. These differences were probably consistent, but not solely attributable, to differences in local guidelines and reimbursement policies.

Key words: utilisation of medicines, ATC/DDD methodology, international comparisons, rational use.

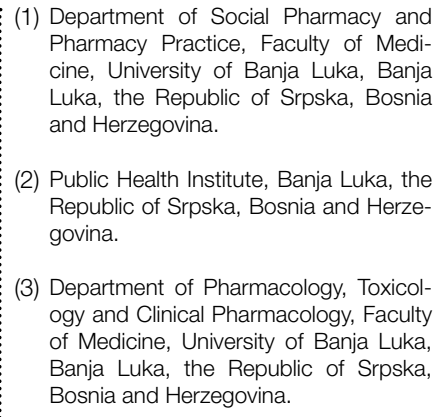
Pharmacy Practice, Faculty of Medicine, University of Banja Luka, Banja Luka, the Republic of Srpska, Bosnia and Herzegovina.

(2) Public Health Institute, Banja Luka, the Republic of Srpska, Bosnia and Herzegovina.

(3) Department of Pharmacology, Toxicology and Clinical Pharmacology, Faculty of Medicine, University of Banja Luka, Banja Luka, the Republic of Srpska, Bosnia and Herzegovina.

Correspondence:

VANDA MARKOVIĆ-PEKOVIĆ

E: vanda.markovic-pekovic@med.unibl.org

\section{ARTICLE INFO}

Received: 23 October 2019 Revision received: 4 November 2019 Accepted: 7 November 2019

\section{INTRODUCTION}

Medicines are only one component in the maintenance and restoration of the health of communities and individuals, and are segment in the prevention, diagnosis and treatment of dis- eases. If used appropriately, medicines have the potential to relieve suffering from disease and to restore health, which is why they are placed amongst the top priorities in every health sys-

Copyright $\odot 2019$ Marković-Peković et al. This is an open access article distributed under the Creative Commons Attribution License (CC BY), which permits unrestricted use, distribution, and reproduction in any medium, provided the original work is properly cited. This article should be cited as follows: Marković-Peković V, Ljubica Bojanić Lj, Stoisavljević-Šatara S. The characteristics of the outpatient utilisation of medicines in the Republic of Srpska in the period 2009-2017. Scr Med 2019;50(4):167-76. 
tem. ${ }^{1}$ With their pharmacological properties, economic impact on health systems and environmental impact, utilisation of medicines exerts important effects on health systems. As in general, consumption of medicines continues to increase, ${ }^{2-4}$ the knowledge of the quantitative and qualitative patterns of medicines use is a key element for allocation of health care resources and development of sustainable health policy. In 2016, after inpatient and outpatient care, medicines represented the third largest item of health care spending and accounted for one-sixth of health expenditure in the European Union, thus confirming the vital role that medicines have in the health system. ${ }^{5}$

Systematic use of routinely collected data on medicines can be employed in assessing the value of medicines in use in health care systems, and can give an insight in the efficiency, quality and fairness of health services. ${ }^{6}$ Monitoring and measuring of the medicines use enables to assess quality use of medicines, to identify areas of suboptimal medicines use and provide feedback to prescribers, and thus improvement of pharmacotherapy. The volume of prescribed medicines may be affected by a number of factors, such as population size and age, disease prevalence, changes in medical practice, prescriber and patient behaviour, developments in medical practice, new medicines, reimbursement policies, new guidelines that adjust the recommended treatment per patient or which enlarge the population of patients who would benefit from the treatment. ${ }^{7,8}$ Our country, like other countries in transition, is characterised by the demographic shift, with an increase in life expectancy and population aging. ${ }^{9}$ So, the major burden of diseases is shifted toward the whole range of chronic diseases, and clinical guidelines were developed for the most common non-communicable diseases..$^{10}$ At the same time the legislative and organisational system for collecting the data on the medicines utilisation has been established.

Previous studies conducted by our research group have shown the importance of continuous monitoring and analysing of medicines utilisation and expenditure patterns in the population. 4,8 These studies enabled us to assess the influence of multiple measures introduced in our healthcare system in recent years to increase prescribing efficiency, and furthermore to suggest additional reforms or measures to further enhance the prescribing efficiency. With the aging of our population and the increasing prevalence of multiple medicinal conditions in the elderly, the share of the long-term medicine use has increased proportionally. This points out the public health importance of the utilisation patterns analyses in the elderly population with the aim to optimise drug prescribing for this group. Understanding of current patterns in medicines use is important to support pharmaceutical policy implementation as a part of a sustainable health policy, considering the expected health outcomes and the related impact to the medication expenditure.

In order to continue with the monitoring and evaluation of the utilisation of medicines in our country, the aim of this study was to analyse the utilisation patterns of medicines and to compare the results with the ones in other countries.

\section{METHODS}

This was a retrospective, observational study on outpatient medicines use over the period from 2009 to 2017. Data was retrieved from the national database located in the Public Institute of Health (PHI). Reports on all medicines dispensed to the patients in all retail pharmacies were sent annually to PHI for collation. This period was chosen as PHI has been collecting and processing data since 2009.

Medicines utilisation was calculated using the Anatomical Therapeutic Chemical/Defined Daily Dose (ATC/DDD) methodology,11 as the internationally accepted methodology for measuring medicines utilisation.12-16 The ATC system classifies medicines into different groups according to the organ or system on which they act and their chemical, pharmacological and therapeutic properties. Medicines were classified into ATC groups by its international non-proprietary name. The results were expressed as a DDD per thousand inhabitants per day (DDDs). DDD is the assumed average maintenance dose per day for a drug used for its main indication in adults. It is a technical, statistical unit of measurement and does not necessarily reflect the recommended or actual used daily dose. DDD is a tool for national and international compar- 
isons between different geographical areas and health facilities.11 Descriptive analyses on the data were performed. Data were expressed as absolute numbers with or without percentages.
All analyses were undertaken using Microsoft Excel 2010 program. The results were presented in tables.

\section{RESULTS}

Total medicines utilisation increased, from 448 DDDs in 2009, to 1036 DDDs in 2017. The utilisation increased in almost all anatomical groups, and the highest increase was observed in groups C (cardiovascular system), B (blood and blood forming organs) and A (alimentary tract and metabolism). Group $\mathrm{C}$ medicines share in the total utilisation of medicines increased from $36.6 \%$ in 2009 , to $44.4 \%$ in 2017 (Table 1 ).

Medicines acting on the renin-angiotensin system (Co9) and calcium channel blockers (Co8) had a highest utilisation in the group C. The Co9 group share in the total medicine utilisation increased from $15.7 \%$ (2009) to $24.6 \%$ (2017) (Table 2), and the most prescribed were angiotensin-converting enzyme inhibitors (ACEIs), plain (Co9A) and in combinations (Co9B) (Table 3). The share of the medicines used in diabetes (A10) in the total medicine utilisation increased from $3.9 \%$ (2009) to 5.1\% (2017) (Table 2). In total medicines utilisation, the share of psycho- leptics (No5) ranged from 4.5\% (2009) to 3.4 $\%$ (2017) and of psychoanaleptics (No6) from $1.3 \%$ (2009) to $1.9 \%$ (2017) (Table 2). Anxiolytics were the most prescribed among psycholeptics (Table 3), namely diazepam followed by alprazolam. Utilisation of antidepressants has grown steadily and has increased 3.5 -fold during the observed period (4.7 DDDs in 2009 vs 16.7 DDDs in 2017).

Utilisation of drugs for obstructive pulmonary diseases (Ro3) has increased 2.5-fold in number of DDDs and the share in the total medicine utilisation increased from $1.4 \%$ (2010) to $1.9 \%$ (2017) (Table 2).

Among calcium channel blockers (CCBs), selective CCBs with mainly vascular effects (Co8C) were prescribed the most, with about seven percent share in total medicines utilisation (Table 3). A continuous increase in the utilisation of drugs for acid-related disorders (A02) was

Table 1: Total utilisation of medicines at the level of main anatomical groups (ATC level I), in number of DDDs

\begin{tabular}{|c|c|c|c|c|c|c|c|c|c|c|}
\hline $\begin{array}{l}\text { ATC } \\
\text { code }\end{array}$ & Anatomical group & 2009 & 2010 & 2011 & 2012 & 2013 & 2014 & 2015 & 2016 & 2017 \\
\hline $\mathrm{C}$ & Cardiovascular system & 163.8 & 242.9 & 294.4 & 285.4 & 300.9 & 338.7 & 348.7 & 422.9 & 460.2 \\
\hline B & Blood and blood forming organs & 52.8 & 82.7 & 99.4 & 94.3 & 97.1 & 111.2 & 127.6 & 130.2 & 131.3 \\
\hline A & Alimentary tract and metabolism & 60.3 & 70.8 & 105.6 & 105.3 & 106.7 & 110.4 & 108.1 & 123.1 & 126.6 \\
\hline N & Nervous system & 74.1 & 93.5 & 94.0 & 94.3 & 99.5 & 102.4 & 99.3 & 84.8 & 96.0 \\
\hline M & Musculo-skeletal system & 17.1 & 39.6 & 48.2 & 47.7 & 50.4 & 56.5 & 55.5 & 65.6 & 71.1 \\
\hline $\mathrm{R}$ & Respiratory system & 24.2 & 26.5 & 27.3 & 23.9 & 26.3 & 30.7 & 34.6 & 39.5 & 39.2 \\
\hline G & Genito urinary system and sex hormones & 6.7 & 12.3 & 13.9 & 15.4 & 14.9 & 16.2 & 18.3 & 21.9 & 24.5 \\
\hline D & Dermatologicals & 10.3 & 15.4 & 19.9 & 22.4 & 23.2 & 28.0 & 20.4 & 24.0 & 23.6 \\
\hline $\mathrm{J}$ & Antiinfectives for systemic use & 20.7 & 18.1 & 18.0 & 16.0 & 18.7 & 15.8 & 17.7 & 20.0 & 23.2 \\
\hline $\mathrm{H}$ & $\begin{array}{l}\text { Systemic hormonal preparations, excl. sex } \\
\text { hormones and insulins }\end{array}$ & 10.0 & 8.5 & 11.2 & 12.2 & 11.8 & 14.8 & 14.8 & 20.2 & 21.7 \\
\hline S & Sensory organs & 7.3 & 9.4 & 10.9 & 10.6 & 10.9 & 12.8 & 13.3 & 14.8 & 15.9 \\
\hline L & Antineoplastic and immunomodulating agents & 0.7 & 2.5 & 1.9 & 2.1 & 2.1 & 2.2 & 2.7 & 2.5 & 2.9 \\
\hline \multirow[t]{2}{*}{$P$} & $\begin{array}{l}\text { Antiparasitic products, insecticides and } \\
\text { repellents }\end{array}$ & 0.7 & 2.5 & 1.9 & 2.1 & 2.1 & 2.2 & 2.7 & 2.5 & 2.9 \\
\hline & Total & 448.2 & 622.3 & 746.5 & 731.5 & 764.3 & 841.7 & 861.2 & 969.5 & 1036.3 \\
\hline
\end{tabular}


Table 2: Total medicines utilisation of 20 most prescribed therapeutic groups (ATC level II), in number of DDDs

\begin{tabular}{|c|c|c|c|c|c|c|c|c|c|c|}
\hline $\begin{array}{l}\text { ATC } \\
\text { code }\end{array}$ & Therapeutic group & 2009 & 2010 & 2011 & 2012 & 2013 & 2014 & 2015 & 2016 & 2017 \\
\hline $\operatorname{Cog}$ & Agents acting on the renin-angiotensin system & 70.4 & 106.4 & 138.7 & 135.8 & 148.6 & 167.8 & 187.5 & 229.2 & 254.8 \\
\hline B01 & Antithrombotic agents & 30.3 & 46.8 & 54.8 & 55.1 & 58.9 & 67.9 & 86.6 & 84.9 & 89.5 \\
\hline $\mathrm{C08}$ & Calcium channel blockers & 30.5 & 42.5 & 50.3 & 48.4 & 53.8 & 64.2 & 56.6 & 70.0 & 72.4 \\
\hline A10 & Drugs used in diabetes & 17.3 & 23.2 & 34.3 & 33.5 & 35.5 & 39.1 & 41.9 & 52.3 & 52.8 \\
\hline M01 & Antiinflamatory and antirheumatic products & 16.1 & 25.3 & 30.4 & 30.5 & 31.7 & 35.4 & 34.9 & 40.8 & 46.1 \\
\hline B03 & Antianemic preparations & 21.2 & 34.6 & 43.7 & 35.3 & 34.5 & 39.8 & 35.5 & 44.8 & 41.4 \\
\hline $\mathrm{C} 07$ & Beta blocking agents & 11.9 & 16.4 & 21.3 & 20.6 & 22.8 & 25.5 & 26.9 & 34.1 & 40.2 \\
\hline N05 & Psycholeptics & 20.0 & 29.2 & 33.2 & 29.3 & 29.4 & 31.7 & 33.7 & 36.5 & 35.5 \\
\hline $\mathrm{A} 02$ & Drugs for acid related disorders & 10.9 & 12.9 & 19.3 & 21.7 & 21.3 & 23.2 & 21.9 & 28.0 & 30.4 \\
\hline A11 & Vitamins & 24.0 & 22.1 & 38.4 & 31.7 & 32.7 & 30.3 & 24.9 & 27.6 & 29.0 \\
\hline $\mathrm{CO3}$ & Diuretics & 11.4 & 21.0 & 20.5 & 21.7 & 20.3 & 22.0 & 24.4 & 27.0 & 28.9 \\
\hline C01 & Cardiac therapy & 20.9 & 27.9 & 33.2 & 31.5 & 27.4 & 28.8 & 23.1 & 26.7 & 27.3 \\
\hline N02 & Analgesics & 41.0 & 46.7 & 39.1 & 42.3 & 54.0 & 44.9 & 37.9 & 16.5 & 25.0 \\
\hline J01 & Antibacterials for systemic use & 20.2 & 17.6 & 17.5 & 15.7 & 18.4 & 15.6 & 16.8 & 19.8 & 23.1 \\
\hline M02 & Topical products for joint and muscular pain & 0.3 & 13.2 & 16.2 & 15.3 & 16.5 & 18.5 & 18.6 & 21.7 & 21.7 \\
\hline N06 & Psychoanaleptics & 5.7 & 7.9 & 11.0 & 11.9 & 12.5 & 14.3 & 14.4 & 17.6 & 20.4 \\
\hline C10 & Lipid modifying agents & 7.8 & 12.8 & 9.1 & 9.6 & 10.2 & 12.3 & 13.5 & 18.8 & 20.0 \\
\hline R03 & Drugs for obstructive airway diseases & 8.1 & 8.6 & 10.4 & 9.7 & 10.6 & 12.3 & 15.2 & 19.3 & 19.6 \\
\hline $\mathrm{H} 03$ & Thyroid therapy & 8.1 & 8.6 & 10.4 & 9.7 & 10.6 & 12.3 & 15.2 & 19.3 & 19.6 \\
\hline G04 & Urologicals & 1.6 & 2.3 & 4.6 & 5.9 & 6.5 & 8.2 & 10.2 & 12.6 & 15.0 \\
\hline
\end{tabular}

observed, with the share in the total medicine utilisation of about $3 \%$ (Table 2). The most prescribed were drugs for peptic ulcer and gas- tro-oesophageal reflux disease (A02B) (Table 3), namely proton pump inhibitor pantoprazole and H2-receptor antagonist ranitidine (Table 4).

Table 3: Total utilisation of ten most prescribed pharmacological groups (ATC level III), in number of DDDs

\begin{tabular}{|c|c|c|c|c|c|c|c|c|c|c|}
\hline $\begin{array}{l}\text { ATC } \\
\text { code }\end{array}$ & Pharmacological group & 2009 & 2010 & 2011 & 2012 & 2013 & 2014 & 2015 & 2016 & 2017 \\
\hline C09 & $\begin{array}{l}\text { Angiotensin-converting-enzyme (ACE) } \\
\text { inhibitors, plain }\end{array}$ & 46.7 & 70.9 & 93.7 & 91.6 & 96.8 & 109.3 & 118.7 & 147.2 & 154.8 \\
\hline B01A & Antithrombotic agents & 46.7 & 70.9 & 93.7 & 91.6 & 96.8 & 109.3 & 118.7 & 147.2 & 154.8 \\
\hline CO9B & $\begin{array}{l}\text { Angiotensin-converting-enzyme (ACE) } \\
\text { inhibitors, combinations }\end{array}$ & 30.3 & 46.8 & 54.8 & 55.1 & 58.9 & 67.9 & 86.6 & 84.9 & 89.5 \\
\hline $\mathrm{CO8C}$ & $\begin{array}{l}\text { Selective calcium channel blockers with } \\
\text { mainly vascular effects }\end{array}$ & 27.8 & 39.0 & 46.5 & 45.1 & 50.8 & 61.2 & 53.7 & 66.7 & 69.5 \\
\hline M01A & $\begin{array}{l}\text { Antiinflamatory and antirheumatic products, } \\
\text { non-steroids }\end{array}$ & 16.1 & 25.3 & 30.3 & 30.5 & 31.7 & 35.4 & 34.9 & 40.8 & 48.1 \\
\hline A10B & Blood glucose lowering agents, excl. insulins & 12.7 & 18.0 & 28.9 & 28.3 & 30.4 & 34.5 & 35.8 & 44.9 & 46.8 \\
\hline CO7A & Beta blocking agents & 11.9 & 16.4 & 21.3 & 20.6 & 22.7 & 25.4 & 26.7 & 33.8 & 37.8 \\
\hline B03B & Vitamin B12 and folic acid & 15.3 & 27.1 & 35.6 & 30.0 & 29.6 & 33.9 & 30.9 & 35.3 & 32.1 \\
\hline A02B & $\begin{array}{l}\text { Drugs for peptic ulcer and gastro-oesophageal } \\
\text { reflux disease }\end{array}$ & 10.3 & 11.9 & 18.6 & 21.1 & 20.8 & 22.6 & 21.6 & 27.6 & 30.3 \\
\hline N5B & Anxiolytics & 17.5 & 24.9 & 28.8 & 25.5 & 25.2 & 27.4 & 28.8 & 30.4 & 30.0 \\
\hline
\end{tabular}


Among the antithrombotic medicines (Bo1A), the most frequently used were platelet aggregation inhibitors excluding heparin (Bo1AC), namely acetylsalicylic acid whose use tripled since 2009 (Table 4). The most frequently used were blood glucose lowering medicines, excluding insulin the combination of paracetamol with caffeine, codeine and propyphenazone. The high-ceiling diuretics comprised about $2 / 3$ of diuretics (Co3) utilisation and furosemide was the most prescribed (Table 4).

Table 4: Twenty most prescribed medicines, in DDDs

\begin{tabular}{|c|c|c|c|c|c|c|c|c|c|c|}
\hline $\begin{array}{l}\text { ATC } \\
\text { code }\end{array}$ & INN & 2009 & 2010 & 2011 & 2012 & 2013 & 2014 & 2015 & 2016 & 2017 \\
\hline C09AA02 & enalapril & 34.3 & 49.0 & 63.3 & 61.7 & 67.2 & 74.5 & 80.3 & 94.0 & 96.5 \\
\hline B01AC06 & acetylsalicylic acid & 45.7 & 45.5 & 49.6 & 50.1 & 53.6 & 63.1 & 81.0 & 78.2 & 82.2 \\
\hline C08CA01 & amlodipine & 32.6 & 35.5 & 41.6 & 40.1 & 45.0 & 53.6 & 45.9 & 53.8 & 53.8 \\
\hline C09BA02 & enalapril, hydrochlorothiazide & 15.5 & 23.1 & 28.8 & 27.6 & 32.0 & 33.1 & 39.1 & 41.7 & 52.7 \\
\hline C09AA05 & ramipril & 3.1 & 6.1 & 11.1 & 12.6 & 13.0 & 13.8 & 17.6 & 26.3 & 30.3 \\
\hline A10BA02 & metformin & 5.1 & 7.6 & 11.1 & 15.9 & 13.6 & 16.2 & 18.0 & 23.6 & 26.1 \\
\hline M01AB05 & diclofenac & 10.3 & 16.2 & 19.1 & 19.5 & 19.4 & 20.5 & 20.7 & 21.6 & 25.0 \\
\hline В03ВВ01 & folic acid & 0.6 & 0.7 & 20.3 & 21.1 & 18.5 & 17.8 & 18.3 & 22.4 & 21.4 \\
\hline N02BE51 & $\begin{array}{l}\text { codeine, caffeine, paracetamol, } \\
\text { propyphenazone }\end{array}$ & 3.4 & 26.3 & 19.8 & 22.1 & 20.3 & 19.5 & 19.0 & 16.8 & 20.2 \\
\hline C03CA01 & furosemide & 5.5 & 11.1 & 10.6 & 12.8 & 11.3 & 12.3 & 13.5 & 16.8 & 18.4 \\
\hline N02BE01 & paracetamol & 3.1 & 3.4 & 4.3 & 5.6 & 9.2 & 6.8 & 7.5 & 9.6 & 18.2 \\
\hline C07AB02 & metoprolol & 5.9 & 8.6 & 10.6 & 10.1 & 11.2 & 12.3 & 12.1 & 14.2 & 17.0 \\
\hline A02BC02 & pantoprazole & 0.6 & 1.2 & 2.1 & 2.8 & 4.1 & 7.0 & 7.3 & 11.4 & 14.0 \\
\hline A02BA02 & ranitidine & 7.2 & 6.8 & 11.9 & 14.2 & 13.0 & 12.6 & 12.0 & 14.0 & 13.8 \\
\hline $\mathrm{A} 11 \mathrm{GA} 01$ & ascorbic acid & 16.1 & 13.3 & 12.7 & 10.7 & 16.0 & 13.7 & 12.4 & 12.8 & 13.6 \\
\hline H03AA01 & levothyroxine & 4.0 & 3.0 & 5.6 & 5.6 & 6.3 & 8.5 & 8.1 & 11.8 & 13.1 \\
\hline С09AА03 & lisinopril & 2.2 & 3.3 & 5.1 & 5.6 & 5.9 & 6.7 & 8.1 & 10.8 & 12.7 \\
\hline A10BB12 & glimepiride & 0.5 & 1.4 & 2.6 & 3.8 & 5.8 & 8.3 & 9.0 & 12.1 & 12.5 \\
\hline C10AA05 & atorvastatin & 4.5 & 7.8 & 5.5 & 5.2 & 5.6 & 7.6 & 8.0 & 11.7 & 12.4 \\
\hline С07AB07 & bisoprolol & 0.5 & 0.1 & 2.1 & 2.6 & 3.8 & 5.1 & 6.4 & 9.8 & 12.0 \\
\hline
\end{tabular}

INN, International Non-proprietary Name

(A10B) (Table 3), namely metformin and glimepiride who accounted about $83 \%$ of A1oB group utilisation (Table 4). Non-steroid (Mo1A) medicines were the most used among anti-inflammatory and antirheumatic medicines (Mo1) (Table 3), specifically diclofenac (Table 4).

Four out of five most prescribed medicines were cardiovascular medicines. Plain ACEI enalapril was the most frequently used, with the increased share in the total medicines' utilisation from $7.6 \%$ (2009) to 9.3\% (2017). Amlodipine was the dominantly prescribed selective CCBs. Consumption of non-opioid analgesics (No2B) dominated among analgesics (No2), namely

\section{DISSCUSION}

This study revealed an increasing trend toward the utilisation of medicines, and given the previous studies ${ }^{17,18}$ it was not a surprising finding. Similar trend was observed in other studies. ${ }^{2-4,7}$ The quantity of medicines tends to increase over time in most therapeutic classes, which may be explained by population ageing, the rise in the prevalence of chronic diseases such as cancer and diabetes, the availability of new medicine treatments or changes in the physicians' prescribing practices, ${ }^{19}$ that may have had an influence on our patterns of medicines utilisation, too. 
Medicines classes used for treatment of the most common chronic non-communicable diseases were of the highest degree of utilisation, ${ }^{9,}{ }^{20}$ as in other countries. ${ }^{21-26}$ Premature mortality related to the major non-communicable diseases can be reduced if appropriate, timely and collective action is taken. ${ }^{27-29}$ Among the other activities undertaken towards improvement of health of the population,,$^{30}$ an update of reimbursable medicines list was carried out precisely to provide better therapeutic choice of medicines, contributing thus to the reduction of morbidity and mortality. Although major non-communicable diseases affect people of all ages, they are often associated with older age groups. Our population is evidently aging as the share of elderly ( $\geq 65$ years) has increased, from $18 \%$ (2007) to 22\% (2014), and of people aged 50-64 years, from $19 \%$ (2010) to 23\% (2014). As the trend in ageing of population has significantly increased over the time, it directly influenced the volume of medicines needed for care of elderly people since they have multiple chronic diseases and requires larger number of prescriptions. A recent study among elderly patients has showed an increase of those who use more medicines for longer period of time, with an increased polypharmacy prevalence (use of $\geq 5$ different medicines). ${ }^{8}$

Cardiovascular (CV) medicines were the most frequently prescribed, like in other countries. ${ }^{21-26,31,32}$ The trend of steady increase in the $\mathrm{CV}$ medicines use has been seen over the last few decades ${ }^{33}$ as they are key elements in preventing and treating CV diseases, which are the leading cause of death and disability worldwide. ${ }^{34-36}$ It has also been a leading cause of our population's mortality for the last 20 years..$^{9,37}$ The health policy planners therefore focused their attention on a national CV programme, implementation of the national and European guidelines ${ }^{38-42}$ and selection of the reimbursed medicines. A decrease in CV mortality, from $53.6 \%$ in 2002 to $48.7 \%$ in $2016^{9,17}$ might be attributable to improved CV care, including pharmacotherapy, as the association between the increase in CV medicines use and a decrease in CV mortality was confirmed. ${ }^{43,44}$ Despite the significant increase in CV medicines use, the mortality rate was rather high and CV diseases has remained a leading cause of morbidity and mortality. 44

The highest utilisation of antihypertensive medicines, such as ACEIs, CCBs and beta blockers, and the increased utilisation of diuretics, are in accordance with clinical guidelines for hypertension. These medicines, with ARBs, are major classes for the treatment of hypertension, used either as monotherapy or in combination with other drugs (mainly diuretics). Over the past 20 years a constant increase in utilisation of these classes was noticed. ${ }^{45}$ Enalapril as a monotherapy and in combination with hydrochlorothiazide was the most used ACEI, followed with ramipril (monotherapy) and lisinopril (combination). As a monotherapy, the ACEIs were also frequently prescribed in Serbia, ${ }^{21,23}$ Finland ${ }^{46}$ and Norway. ${ }^{31}$ High use of ACEIs in combination with diuretics was not surprising, because treatment of hypertension should be preferentially based on combinations of ACEIs or ARBs with a CCB and/or a thiazide diuretic as the most effective evidence-based treatment strategy to improve blood pressure..$^{2}$ These combinations are available on our market in a single pill and in a range of doses, enabling simplification of treatment, flexible prescribing and better patient adherence. Country differences were noticed in the preferred ACEIs ${ }^{23,}$ 24, 26, 31, 32, 47 and ARBs. ${ }^{23,}$ 24, 31, 46 They may be influenced by the recommendation to assess the clinical effects, which are proven to be divergent today, of each medicine and their indications in light of the comorbidities. ${ }^{48}$

Although amlodipine was the most preferred $\mathrm{CCB}$, an increase in lercanidipine utilisation was notable (rising from 0.5 DDDs in 2011 to 11 DDDs in 2017). This trend was noticed in other countries $^{23-25}$, 31, and could be explained by more favourable tolerability profile. ${ }^{49}$ It is a medicine of a higher cost within the class, ${ }^{50,51}$ and value for money is also an important consideration when choosing a preferred medicine. Patients should be provided with a medication appropriate to their clinical needs and at the lowest cost to them and health system. Acetylsalicylic acid was the most frequently used among the antithrombotic medicines, as generally considered effective for the secondary prevention of cardiovascular disease and one of the most frequently used drugs worldwide..$^{2}$

Among statins, atorvastatin was the most prescribed, with the growth in rosuvastatin use (0.7 DDDs in 2011; 5.6 DDDs in 2017). The cross-country variations in the statin use was also noticed by other authors. ${ }^{53}$ Atorvastatin reference prices were higher than those of simvastatin, while rosuvastatin was the most expensive 
statin. Therapeutic switch from rosuvastatin to atorvastatin was not associated with any differences in safety or lipid control, but resulted in significant drug cost savings. ${ }^{54}$ Some studies suggest a continued suboptimal prescribing of lipid lowering medicines in CV population along with the expansion of its use, a shift in use towards asymptomatic and older populations, and overtreatment of people who are unlikely to benefit from this therapy. ${ }^{33}$ Further studies of statin use are needed for deeper analysis.

Diabetes was the fifth leading cause of death in women and the seventh in men in 2016. ${ }^{9}$ Endocrine, nutritional and metabolic diseases (ICD Eoo-E90) accounted for about 3\% in the total morbidity since 2010.9, 55 This chronic disease requires continuous medical care, including expenditure in pharmaceutical supplies. Therefore, besides biguanides and sulphonylureas (SUs), during this follow-up period new oral antidiabetic medicine classes became reimbursed, as dipeptidyl peptidase 4 (DPP-4) inhibitors, glucagon-like peptide-1 (GLP-1) analogues and sodium-glucose co-transporter 2 (SGLT2) inhibitors. An increasing trend in the utilisation of metformin and glimepiride may be influenced by the guidelines that suggest metformin as a first choice ${ }^{56-58}$ and SUs as an initial drug treatment if metformin is contraindicated or not tolerated, or as a dual therapy with metformin if initial treatment with metformin has not reached the patient's individual goals. ${ }^{57}$ International comparisons showed an increasing trend in metformin use, and at the same time by decrease in SUs use. ${ }^{46,59-61}$ We have also noticed a decrease in the use of other available SUs, except for glimepiride. Pharmaceutical marketing might have had some influence on prescribing the first choice among the SUs, as pointed out by Pavlov in Croatia. ${ }^{62}$ This possible influence should be clarified in future research. DPP-4 and GLP-1 were less frequently used but an increase in their use was also observed.

Utilisation of proton pump inhibitors (PPIs) and especially of pantoprazole has steadily grown, as elsewhere. ${ }^{24,25,31,46}$ Several PPIs, including pantoprazole, were reimbursed, and pantoprazole is the only one also available on the market as a non-prescription medicine (20 mg dose). Ranitidine utilisation was high compared to the other countries. ${ }^{24,25,31,46}$ At low doses (75 mg) it is available on our market as an over-the-counter (OTC) medicine. The reason for its still wide use, despite the availability of the more effective acid-suppressant PPIs, is to be further explored. A decreasing trend in the use of diclofenac was expected regarding the new scientific evidences about its safety profile, i.e. cardiovascular side effects, as informed by the Agency of Medicines and Medical Devices of Bosnia and Herzegovina at the beginning of 2014. Moreover, this is a sole prescription medicine for oral use. In other countries ibuprofen is preferred due to a better safety profile and more OTC medicines available in pharmacies because of which diclofenac exhibits a declining trend. ${ }^{24,25,31,46}$ Ibuprofen utilisation has grown over the period.

The strength of this study is a nine-year follow-up period, a timeline that is long enough to allow for the determination of the existing trends. The medicines utilisation data came from the official national source, thus providing robustness. Data built on the medicines dispensed to patients were considered as a strength, although there was awareness that it does not necessarily ensure that the medicine was taken by the patient. The nature of the data in this administrative database that allowed only determination of trends may be considered as a limitation. More in depth analysis could be performed with available data on the age, gender, diagnosis, clinical information, changes in medicines use, therapy intensification, medication duration etc. Beyond the limitations, these results can serve as a starting point for further studies about the use of medicines and its rationality.

\section{CONCLUSION}

The utilisation of medicines showed an increasing trend, which is similar to other countries. In addition to the similarities, certain differences in the use of medicines were also observed among the countries, as variations in the preferred medicines within a class and the extent of medicines use. These differences were probably consistent, but not solely attributable, to differences in local guidelines and reimbursement policies. Value for money, for health system and patients who pay for their own medicines, is an important consideration when choosing a preferred medicine according to scientific evidence and the patient's needs. 


\section{ACKNOWLEDGEMENTS}

None.

\section{CONFLICT OF INTEREST}

\section{REFERENCES}

1. Republic of Srpska Government. National Medicines Policy. Banja Luka: Ministry of Health and Social Welfare, 2006.

2. The Organisation for Economic Co-operation and Development (OECD). Health at a Glance 2017: OECD Indicators [Internet]. Paris: OECD Publishing. 2017. [cited $2019 \mathrm{Jul}$ 4]; Available from: http://www. oecd-library.

3. Zhang F, Mamtani R, Scott FI, Goldberg DS, Haynes $\mathrm{K}$, Lewis JD. Increasing use of prescription drugs in the United Kingdom. Pharmacoepidemiol Drug Saf 2016;25(6):628-36.

4. Markovic-Pekovic V, Škrbić R, Godman B, Gustafsson LL. Ongoing initiatives in the Republic of Srpska to enhance prescribing efficiency: Influence and future directions. Expert Rev Pharmacoecon Outcomes Res 2012;12(5):661-71.

5. The Organisation for Economic Co-operation and Development (OECD). Health at a Glance 2018: OECD Indicators [Internet]. Paris: OECD Publishing. 2018. [cited 2019 Jul 4]; Available from: http://www. oecd-library.

6. Richards M. A report for the Secretary of State for Health by Professor Sir Mike Richards: Extent and causes of international variations in drug usage [Internet]. London: Crown Copyright. 2010. [cited 2019 Sep 4]. Available from http://assets.publishing.service.gov.uk/government/uploads/system/uploads/ attachment_data/file/216249/dh_117977.pdf.

7. Ewbank L, Omojomolo D, Sullivan K, McKenna H. The rising cost of medicines to the NHS. What's the story? Briefing [Internet]. London: The Kings Fund, [cited 2019 Jul 4]. Available from. 2018. [cited 2019 Jul 4]; Available from: http://www.kingsfund.org. uk/sites/default/files/2018-04/Rising-cost-of-medicines.pdf.

8. Marković-Peković V, Škrbić R, Petrović A, Vlahović-Palčevski V, Mrak J, Bennie M, et al. Polypharmacy among the elderly in the Republic of Srpska: extent and implications for the future. Expert Rev Pharmacoecon Outcomes Res 2016;16(5):609-18.

9. Republika Srpska Institute for Statistics. Women and men in Republika Srpska. Bulletin No 9. [Internet]. Banja Luka: Republički zavod za statistiku. 2017. [cited 2019 Sep 15]; Available from: http://www.rzs. rs.ba.

10. Ministry of Health and Social Welfare of the Republic of Srpska. Guidelines for clinical practice [Internet]. Banja Luka: Ministry of Health and Social Welfare of the Republic of Srpska, 2004. [cited 2019 Jul 4]; Available from: http://www.vladars.net.

11. WHO Collaborating Centre for Drug Statistics Methodology. ATC/DDD Index 2019 [Internet]. Oslo: WHO Collaborating Centre for Drug Statistics Meth-
None.

odology. 2019. [cited 2019 Jul 17]; Available from: http://www.whocc.no/.

12. Patel S, Shah A, Shah R, Buch J. Evaluation of drug utilisation pattern of antimicrobials using ATC/ DDD system in intensive care unit of a tertiary-care teaching hospital. Int $\mathrm{J}$ Med Sci Public Health 2016;5(1):80-4.

13. Rosli R, Dali AF, Abd Aziz AN, Abdullah AH, Ming LC, Manan MM. Drug utilisation on neonatal wards: a systematic review of observational studies. Front Pharmacol 2017;8:27. doi: 10.3389/fphar.2017.00027

14. Bojanić L, Marković-Peković V, Škrbić R, Stojaković $\mathrm{N}$, Đermanović M, Bojanić J, et al. Recent initiatives in the Republic of Srpska to enhance appropriate use of antibiotics in ambulatory care: their influence and implications. Front Pharmacol 2018;9:445. doi: 10.3389/fphar.2018.00442

15. Versporten A, Bolokhovets G, Ghazaryan L, Abilova V, Pyshnik G, Spasojevic T, et al. Antibiotic use in eastern Europe: a cross-national database study in coordination with the WHO Regional Office for Europe. Lancet Infect 2014;14(5):381-7.

16. Ferrer P, Ballarín E, Sabaté M, Laporte J, Schoonen M, Rottenkolber M, et al. Sources of European drug consumption data at a country level. Int J Public Health 2014;59(5):877-87.

17. Marković-Peković V, Stoisavljević-Šatara S, Škrbić R. Utilisation of cardiovascular medicines in Republic of Srpska, Bosnia and Herzegovina, five years study. Pharmacepidemiol Drug Saf 2009;18(4):320-6.

18. Marković-Peković V, Stoisavljević-Šatara S, Škrbić R. Outpatient utilisation of drugs acting on nervous system: a study from the Republic of Srpska, Bosnia and Herzegovina. Eur J Clin Pharmacol 2010;66(2):17786.

19. Belloni A, Morgan D, Paris V. Pharmaceutical expenditure and policies: past trends and future challenges [Internet]. In: OECD Health Working Papers, no 87. Paris: OECD Publishing. 2016. [cited 2019 Sep 4]; Available from: http://www.oecd-ilibrary.org.

20. Stanetić K, Račić M, Petrović V, Jatić Z, Savić S, Kusmuk S. Prevencija najčeščih hroničnih bolesti [Internet]. Banja Luka: Udruženje doktora porodične medicine; Atlantik bb. 2017. [cited 2019 Sept 7]; Available from: http://porodicnamedicina.com..

21. Agencija za lekove i medicinska sredstva Srbije. Promet i potrošnja gotovih lekova za humanu upotrebu u Republici Srbiji u 2009. godini [Internet]. Beograd: Agencija za lekove i medicinska sredstva Srbije. 2010. [cited 2019 Sep 1]; Available from: https://www. alims.gov.rs.

22. Agencija za lekove i medicinska sredstva Srbije. Promet i potrošnja gotovih lekova za humanu upotrebu u Republici Srbiji u 2010. godini [Internet]. Beograd: 
Agencija za lekove i medicinska sredstva Srbije. 2011. [cited 2019 Sep 1]; Available from: https://www. alims.gov.rs.

23. Agencija za lekove i medicinska sredstva Srbije. Promet i potrošnja gotovih lekova za humanu upotrebu u Republici Srbiji u 2017. godini [Internet]. Beograd: Agencija za lekove i medicinska sredstva Srbije. 2018. [cited 2019 Sep 1]. Available from: https://www. alims.gov.rs.

24. Agencija za lijekove I medicinske proizvode-HALMED. Potrošnja lijekova u Hrvatskoj 2013 - 2017 [Internet]. Zagreb: HALMED. 2018. [cited 2019 Sep 1]; Available from: http://www.halmed.hr.

25. Agencijazalijekoveimedicinske proizvode-HALMED. Potrošnja lijekova u Hrvatskoj 2009 - 2013 [Internet]. Zagreb: HALMED. 2015. [cited 2019 Sep 1]; Available from: http://www.halmed.hr.

26. Agencija za ljekove i medicinska sredstva Crne Gore-CALIMS. Potrošnja ljekova u Crnoj Gori za period 2014-2015.godine [Internet]. Podgorica: CALIMS. 2016. [cited 2019 Sep 1]; Available from: http:// www.calims.me.

27. Ezzati M, Riboli E. Can Noncommunicable Diseases Be Prevented? Lessons from Studies of Populations and Individuals. Science 2012;337(6101):1482-7.

28. Cannon G, Gupta P, Gomes F, Kerner J, Parra W, Weiderpass E, et al. Prevention of cancer and non-communicable diseases. Asian Pac J Cancer Prev 2012;13(4 Suppl):3-11.

29. Mikkelsen B, Williams J, Rakovac I, Wickramasinghe $\mathrm{K}$, Hennis A, Shin H, et al. Life course approach to prevention and control of non-communicable diseases. BMJ 2019;364: l257. doi: 10.1136/bmj.l257.

30. Republic of Srpska Government - Ministry of Health and Social Welfare. Policy for Improvement of Health of the Population in the Republic of Srpska by the Year 2020. Banja Luka: Ministry of Health and Social Welfare, 2012.

31. Sakshaug S. Legemiddelforbruket i Norge 2013-2017 / Drug Consumption in Norway 2013-2017 [Internet]. Oslo: Folkehelseinstituttet. 2018. Legemiddelstatistikk 2018; [cited 2019 Sept 5]; Available from: http://www.fhi.no.

32. Australian Government-Australian Institute of Health and Welfare. Medicines for cardiovascular disease. Canberra: AIHW. 2017. Cat.no CVD 80. [Internet]; [cited 2019 Sept 15]; Available from: http:// www.aihw.gov.au..

33. Polluzzi E, Korhonen MJ. Drug utilisation research in the area of cardiovascular medicines. In: Elseviers M, Wettermark B, Almarsdóttir AB, Andersen M, Benko $\mathrm{R}$, Bennie $\mathrm{M}$ et al, editors. Drug Utilisation Research: Methods and Applications. Chichester, UK: Wiley, 2016. p. 284-93 doi: 10.1002/9781118949740

34. Murray CJ, Vos T, Lozano R, Naghavi M, Flaxman $\mathrm{AD}$, Michaud C, et al. Disability-adjusted life years (DALYs) for 291 diseases and injuries in 21 regions, 1990-2010: a systematic analysis for the Global Burden of Disease Study 2010. Lancet 2012;380:2197223.

35. Roth GA, Johnson C, Abajobir A, Abd-Allah F, Abera SF, Abyu G, et al. Global, Regional, and National Burden of Cardiovascular Diseases for 10 Causes, 1990 to 2015. J Am Coll Cardiol 2017;70(1):1-25.
36. Clark H. NCDs: a challenge to sustainable human development. Lancet 2013;381(9866):510-11.

37. 37. Republika Srpska Institute for Statistics. Women and men in Republika Srpska. Bulletin no 1 [Internet]. Banja Luka: Republički zavod za statistiku. 2003. [cited 2019 sep 15]. Available from: http// www.rzs.rs.ba.

38. Cardiology Society of Republic of Srpska. European Guidelines for the Prevention of Cardiovascular Diseases. Version 2007 [Internet]. Banja Luka: Udruženje kardiologa Republike Srpske. 2007. [cited 2019 Sep 9]. Available from: http://www.kardiolozi-rs.org/.

39. European Society of Cardiology. Lopez-Send J, Swedberg K, McMurray J, Tamargo J, Maggioni AP, Dargie $\mathrm{H}$ et al. Expert consensus document on angiotensin converting enzyme inhibitors in cardiovascular disease. Eur Heart J. 2004;25(16):1454-70. doi: 10.1016/j.ehj.2004.06.003

40. European Society of Cardiology. Ruilope L, Cereso C, Segura J, Garcia-Donaire. Calcium channel blockers and cardiovascular protection. [Internet]. e-journal of the ESC Council for Cardiology Practice 2008; 6: No 28. [cited 2019 Sep 9]. Available from: https:// www.escardio.org.

41. European Society of Cardiology. CVD Prevention in Clinical Practice (European Guidelines on) Guidelines. ESC Clinical Practice Guidelines. Eur Heart J 2016;37:2315-81.

42. European Society of Cardiology. The Task Force for the management of arterial hypertension of the European Society of Cardiology (ESC) and the European Society of Hypertension (ESH). 2018 ESC/ESH Guidelines for the management of arterial hypertension. Eur Heart J 2018;39:3021-104.

43. Weisfeldt ML, Zieman SJ. Advances in the prevention and treatment of cardiovascular disease. Health Aff (Millwood) 2007;26(1):25-37.

44. Lisauskienė I, Garuolienė K, Gulbinovič J. Utilisation of cardiovascular medicines and cardiovascular mortality in Lithuania, Sweden and Norway in 20032012. Medicina (Kaunas) 2017;53(4):259-67.

45. Jarari N, Rao N, Rao PJ, Ellafi KA, Shakila S, Said $\mathrm{AR}$, et al. A review on prescribing patterns of antihypertensive drugs. Clin Hypertens 2016;22:7. doi: 10.1186/s40885-016-0042-0. eCollection 2015.

46. Finnish Medicines Agency Fimea. Drug consumption in years 2014-2017 [Internet]. [cited 2019 Sept 5]. Available from: www.fimea.fi.

47. Sarganas G, Knopf H, Grams D, Neuhauser HK. Trends in antihypertensive medication use and blood pressure control among adults with hypertension in Germany. Am J Hypertens 2015;29(1):104-13.

48. Dézsi CA. The different therapeutic choices with ARBs. Which one to give? When? Why? Am J Cardiovasc Drugs 2016;16(4):255-66.

49. Grassi G, Robles N, Seravalle G, Fici F. Lercanidipine in the management of hypertension: an update. J Pharmacol Pharmacother 2017;8(4):155-65.

50. Health Insurance Fund of the Republika Srpska. Price Lists and Codes. Medicines [Internet]. [cited 2019 Sept 16]. Available from: https://www.zdravstvo-srpske.org/files/cjenovnici/lijekovi.pdf. Serbian.

51. The Agency for Medicinal Products and Medical De- 
vices. Annual reports on the medicines sale in Bosnia and Herzegovina [Internet]. [cited 2019 Sep 10]. Available from: http://www.almbih.gov.ba/.

52. Raber I, McCarthy CP, Vaduganathan M, Bhatt DL, Wood DA, Cleland JGF et al. The rise and fall of aspirin in the primary prevention of cardiovascular disease. Lancet 2019;393(10186):2155-67.

53. Godman B, Sakshaug S, Berg C, Wettermark B, Hay$\operatorname{cox}$ A. Combination of prescribing restrictions and policies to engineer low prices to reduce reimbursement costs. Expert Rev Pharmacoecon Outcomes Res 2011;11(1):121-29.

54. Dowd CM, Tillmann JJ. Therapeutic Interchange from rosuvastatin to atorvastatin in a veteran population. Fed Pract 2015;32(12):20-4.

55. Institute for Statistics, the Republika Srpska. Women and men in the Republic of Srpska. Bulletin no 6. Banja Luka: Republički zavod za statistiku. 2012. Serbian.

56. American Diabetes Association. Pharmacologic approaches to glycemic treatment: standards of medical care in diabetes - 2018. Diabetes Care 2018;41(Supplement 1):S73-S85.

57. National Institute for Health and Care Excellence. Type 2 diabetes in adults: Management (Clinical guideline NG28).[Internet]. London: NICE. 2019. [cited 2019 Sept 15]. Available from: https://www. nice.org.uk/guidance/ng28.

58. Ministry of Health of Republic of Serbia. National clinical guideline diabetes mellitus. Second amended edition. Belgrade: Agency for Accreditation of Health Care Institutions of Serbia, 2012.

59. Montvida O, Shaw J, Atherton JJ, Stringer F, Paul SK. Long-term trends in antidiabetes drug usage in the U.S.: real-world evidence in patients newly diagnosed with type 2 diabetes. Diabetes Care 2018;41(1):69-78.

6o. Wilkinson S, Douglas I, Stirnadel-Farrant H, Fogarty D, Pokrajac A, Smeeth L, et al. Changing use of antidiabetic drugs in the UK: trends in prescribing 2000-2017. BMJ Open 2018;8(eo22768) doi: 10.1136/bmjopen-2018-022768.

61. Moreno Juste A, Menditto E, Orlando V, Monetti VM, Gimeno Miguel A, Gonzales Rubio F, et al. Treatment patterns of diabetes in Italy: a population-based study. Front Pharmacol 2019 Aug 6; 10:870. doi: 10.3389/fphar.2019.00870. eCollection 2019.

62. Pavlov R, Topličan I, Vrcić KM. Ten-year trends in the morbidity of diabetes mellitus and antidiabetic drug utilisation in Croatia: a study based on routinely collected data. Int J Family Med 2016;2016:9837496. doi: 10.1155/2016/9837496. Epub 2016 Jul 4. 